DOI: $10.17951 / \operatorname{lrp} .2020 .40 .1 .55-69$

\author{
MARTA Uberman \\ Uniwersytet Rzeszowski \\ ORCID - 0000-0001-5352-4308
}

\title{
PEDAGOGICZNE KRYTERIA POZNANIA I OCENY RYSUNKÓW DZIECKA W PERSPEKTYWIE MODELU OBRAZOWANIA FIGURATYWNEGO
}

\begin{abstract}
Streszczenie: Wprowadzenie: Błądzenie po omacku, nadmierne teoretyzowanie, subiektywność poznania i oceny twórczości rysunkowej dziecka, zamiast stymulować, motywować i wzmacniać jego poczucie wartości, obniża je i uzależnia od osób dorosłych. Brak wymiernych kryteriów poznania skutkuje powierzchownymi analizami, pochopnymi diagnozami i nieadekwatnymi dla rozwoju i możliwości dziecka ocenami. Cel badań: W artykule dokonano analizy literatury przedmiotu z zakresu twórczości rysunkowej dziecka w okresie obrazowania figuratywnego, skupiając uwagę na ukazaniu jakości wizualnych formy plastycznej, mogących służyć jako wymierne kryterium dla pedagogicznego poznania i obiektywnej oceny dziecięcych rysunków. Udzielono odpowiedzi na pytania: na jakie jakości wizualne formy plastycznej należy zwrócić uwagę? Jak rozwojowo różnicują się pojęcia linii i kształtu, koloru i plamy kolorystycznej, przestrzeni i układu kompozycyjnego? Jakich w związku z tym nowych cech nabywa formalnych rysunek dziecka? Stan wiedzy: Kompleksowo zagadnienie poznania i oceny rysunków dziecka podjął w latach 60. XX wieku Stefan Szuman. Pewne odniesienia do problematyki można odnaleźć w pracach Victora Lowenfelda i Williama L. Brittaina, Rudolfa Arnheima, Stanisława Popka i in. Pedagogicznemu poznaniu i ocenie rysunków dziecka może służyć opis rozwoju formy plastycznej zawarty w modelu obrazowania figuratywnego Marty Uberman. Podsumowanie: Pedagogiczne poznanie i ocena dziecięcej twórczości plastycznej powinna mieć charakter obiektywny, dlatego wymaga elementarnej wiedzy o dziecka i wymiernych kryteriów analizy formy plastycznej.
\end{abstract}

Słowa kluczowe: jakości wizualne formy plastycznej, obrazowanie figuratywne, pedagogiczne poznanie i ocena, rysunek dziecka 


\section{WPROWADZENIE}

Błądzenie po omacku, nadmierne teoretyzowanie, subiektywność poznania i oceny twórczości rysunkowej dziecka, zamiast stymulować, motywować i wzmacniać jego poczucie wartości, obniża je i uzależnia od osób dorosłych. Brak świadomości wyjątkowości twórczości rysunkowej dziecka i wiedzy o jej ewolucji z jednej strony, z drugiej wymiernych kryteriów poznania skutkuje powierzchownymi analizami strukturalnymi wytworów, pochopnymi diagnozami i nieadekwatnymi dla rozwoju poznawczego i percepcyjno-motorycznego ocenami. Słabością praktyki pedagogicznej jest też stosowanie tzw. wyrażeń okazjonalnych rozumianych rozmaicie, zależnie od sytuacji, wiedzy i przygotowania merytorycznego nauczyciela. Podjęta próba ukazania wymiernych kryteriów poznania i oceny rysunków dziecka jest potrzebą i koniecznością praktyki pedagogicznej. Takie podejście badawcze stwarza w pewnym sensie nową perspektywę myślenia o twórczości plastycznej dziecka.

\section{PROBLEM I CEL BADAŃ}

Pedagogika może badać twórczość plastyczną dziecka na dwa sposoby: normatywny bądź opisowy (Wallon, Cambier, Engelhart, 1993). W pierwszym przypadku poszukuje odpowiedzi na pytanie, jak należy poznawać i oceniać rysunki dziecka, w drugim zaś jak się poznaje i ocenia. Niniejszy artykuł powinien udzielić odpowiedzi na drugie pytanie. W wyniku analizy literatury przedmiotu uznano, że jakości wizualne formy plastycznej mogą stanowić obiektywne i wymierne kryterium dla pedagogicznego poznania i oceny rysunków dziecka. Powstają pytania: na jakie jakości wizualne formy plastycznej należy zwrócić uwagę? Jak rozwojowo różnicują się pojęcia linii i kształtu, koloru i plamy kolorystycznej, przestrzeni i układu kompozycyjnego? Jakich w związku z tym nowych cech nabywa formalnych rysunek dziecka? Na te pytania udzielono odpowiedzi w tym artykule.

\section{STAN WIEDZY}

Subiektywizm oceny twórczości plastycznej dziecka, głęboko zakorzeniony w tradycji praktyki pedagogicznej, wynika z dwóch rzeczy: koncepcji sztuki, której osnową jest naśladownictwo, oraz niewiedzy dotyczącej prawidłowości rozwoju formy plastycznej w twórczości rysunkowej dziecka. Dążenie do iluzjonizmu naturalistycznego na dobre zadomowiło się w powszechnej świadomości z hasłem „jak żywe”, powtarzanym przez pokolenia, jako miara wartości dzieła sztuki. 
Nie może być miarą pedagogicznego poznania i oceny rysunków dziecka podobieństwo do natury, ścisłości perspektywicznej, prawdy anatomicznej i materii przedmiotu. Odrysowywanie i odwzorowywanie nie może być normą szkolnej edukacji dziecka, a już zdecydowanie nie edukacji plastycznej (Stern, 2016). Z pełna odpowiedzialnością, w wyniku własnych obserwacji, wysłuchania licznych komentarzy i nauczycieli i rodziców można powiedzieć, że niewiele zmieniło się w tej kwestii w edukacji.

Przeciwieństwem oceny subiektywnej jest ocena obiektywna, bazująca na wiedzy i na wymiernym kluczu analizy formy plastycznej (Popek, 1985). Zagadnienie poznania i oceny rysunków dziecka podjął Stefan Szuman (1990b), który uważa, że w obiektywnym poznaniu i ocenie twórczości plastycznej dziecka należy kierować się: tematem, czyli tym, co zostało przedstawione; graficznym ujęciem rzeczywistości przedmiotowej i określeniem stopnia podobieństwa do natury, oraz układem kompozycyjnym w aspekcie jedności ideowej wytworu. Słusznie kontestuje, że w pedagogicznym poznaniu i ocenie rysunków dziecka ocena powinna być jak najbardziej zobiektywizowana i uzasadniona, oraz zaleca „wyszukanie i wyodrębnienie istotnych punktów widzenia, z jakich ogląda się i rozpatruje rysunki dziecięce, oraz kryteriów, według których się je ocenia i oceniać powinno" (Szuman, 1990b, s. 309). Zaznacza, że „ocena wartości rysunków dziecka” w rzeczywistości pedagogicznej jest dość skomplikowana i trudna, gdyż „wymaga uwzględnienia co najmniej trzech czynników: 1 - umiejętności graficznego i kolorystycznego ukształtowania budowy i wyglądu rzeczy na obrazku; 2 - zainteresowań i emocji, wyrażających się w przedstawieniu graficznym i kolorystycznym danego tematu na obrazku; 3 - przejrzystości i zwięzłości kompozycji obrazu oraz umiejętności powiązania w niej w dobrze zestrojoną i zharmonizowaną całość wszystkich jej elementów" (Szuman, 1990b, s. 310). Szuman swoją wizję poznania i oceny twórczości plastycznej dziecka buduje na podstawie teorii realizmu intelektualnego (Luquet, 1927), która głosi, że dziecko „rysuje to, co wie o przedmiocie, a nie to, co widzi”, idei odrzuconej m.in. przez Claire Golomb (2011), Arno Sterna (2016), Rudolfa Arnheima (2019). Nieco inne, bliższe współczesności, spojrzenie na zagadnienie prezentuje Stanisław Popek (1985). Idea badacza jest bliska teorii rozwoju formy plastycznej dziecka Rudolfa Arnheima, Anny Trojanowskiej (1983), Arno Sterna, Urszuli Szuścik (2018, 2019), ale też wykazuje pewną spójność ideową z myślą Stefana Szumana czy Victora Lowenfelda i Williama L. Brittaina (1977), chociażby w kwestii porównań formy stworzonej z formą rzeczywistą. Należy uznać, że koncepcja Stanisława Popka jest interesująca i może stanowić punkt wyjścia dla ukazania w aspekcie pedagogicznym kryteriów poznania i oceny twórczości plastycznej dziecka. W myśli Popka można odnaleźć wiele wskazań ważnych dla praktyki pedagogicznej, a zamysł badacza dotyczący pogłębionej analizy struktu- 
ralnej wytworów plastycznych należy do jednych z najbardziej trafnych ostatnich lat XX wieku i pierwszych XXI. Jako istotne elementy formy plastycznej Popek podaje: kształt, kompozycję, kolorystykę, walor, charakter środków wyrazowych (plam, linii, kresek, kropek, brył, faktury), jedność ideowa treści i formy (Popek, 1985). Pewne odniesienia do podjętego zagadnienia można odnaleźć w pracach Władysława Lama (1960), Stefana Kościeleckiego (1975), Tadeusza Marciniaka (1976), Jerzego Kujawińskiego (1990), Eleonory Cannoni (2003), Claudio Longobardi, Tiziano Pasta, Rocco Quaglia (2012), Urszuli Szuścik (2018, 2019). Na ogół zajmujący się szeroko pojmowaną twórczością plastyczną dziecka są zgodni co do jednego, że w praktyce pedagogicznej poznanie i ocena wytworów plastycznych powinna opierać się na wymiernych kryteriach analizy jakości wizualnych formy plastycznej.

Wiek przedszkolny i wczesnoszkolny w rozwoju plastycznym dziecka przypada na rozwojowo i twórczo najciekawszy okres, nazywany obrazowaniem figuratywnym (wyobrażeniowo-przedmiotowym). Najpowszechniejszym środkiem wyrazu plastycznego i najbardziej reprezentatywnym w badaniach nad twórczością plastyczną dziecka w tym okresie jest rysunek. Przyjęte tu rozumienie obrazowania figuratywnego osadza się na teoretycznych podstawach czerpanych przede wszystkim z koncepcji Lowenfelda i Brittaina (1977), Szumana (1990a), i Arnheima (2019). Komplementarnym i równorzędnym elementem jego genezy są koncepcje rozwoju poznawczego Jeana Piageta $(1966,1981)$, Lwa S. Wygotskiego (1971), Jerome’a S. Brunera (1982), a także uniwersalne teorie sztuki Ernsta Gombricha (1981), Vasyla Kandyńskiego (1991), Rudolfa Arnheima (2019). Wskazane koncepcje łączy idea pojęciowego charakteru rysunku dziecka. W modelu obrazowania przyswojono za Arnheimem, że pierwsze formy obrazowania są nieodzownymi konstruktami wczesnych koncepcji obrazowych, a ich prostota jest czymś naturalnym i właściwym na poziomie ładu, na którym działa umysł dziecka (Arnheim, 2019). W modelu obrazowania autorka odchodzi się od teorii realizmu intelektualnego. Przyjmuje natomiast tezę o równoważności rozwoju poznawczego, percepcyjno-motorycznego i plastycznego (Lowenfeld, Brittain, 1977; Szuman, 1990b; Gruszczyk-Kolczyńska, 1992; Uberman, 2015; Arnheim, 2019; Szuścik, 2019). Rozwój formy plastycznej w obrazowaniu dziecka jest procesem ciągłym i dynamicznym, w którym podział i łączenie występują naprzemiennie, przy czym „,óżnica między zestawieniem i łączeniem zasadniczych elementów a kształtowaniem jednostek o strukturze bardziej skomplikowanej ma paralele w innych czynnościach umysłu"(Arnheim, 2019, s. 185).

W modelu obrazowania wyodrębniono trzy stadia rozwojowe: pierwsze prefiguratywne z fazą bazgrot (kinestetycznej) i synergii (koordynacji); drugie - motywów figuratywnych z fazą kodyfikacji (symbolizacji) i reifikacji (uprzedmiotowienia); trzecie - utworów figuratywnych $\mathrm{z}$ fazą symplifikacji (schematu) 
i egzemplifikacji (ilustracji) (Uberman, 2015). Punktem wyjścia dla konstruktu obrazowania figuratywnego dziecka stały się ustalenia Gustafa Britscha (1926). W niczym niezakłóconym rozwoju formy plastyczne ukazują się w stałej sekwencji rozwojowej, przy czym każda poprzednia stanowi niezbędny element do pojawienia się kolejnej zgodnie z logiką epigenezy (Lowenfeld, Brittain, 1977; Wallon, Cambier, Engelhart, 1993; Arnheim, 2019; Szuścik, 2019).

Deskrypcja stadiów rozwoju formy plastycznej w okresie obrazowania jest opisem jakościowym elementów wizualnych zgodnie z prawem różnicowania, które mówi, że „rozwój organiczny zawsze przebiega od najprostszego do coraz bardziej złożonego i dopóki jakaś widziana cecha pozostaje nieróżnicowana, cały zakres jej możliwości przedstawiany będzie przez to, co strukturalnie najprostsze" (Arnheim, 2019, s. 185). W praktyce pedagogicznej w poznaniu i ocenie rysunków dziecka, na co słusznie zwraca uwagę Arnheim, ważna jest świadomość tego, że „kiedy dziecko maluje swój portrecik jako prosty wzór - złożony z kółek, owali i kresek - postępuje tak zapewne nie dlatego, że nic więcej nie zobaczyło w lustrze, i nie dlatego, że nie potrafi namalować obrazka wierniejszego, lecz dlatego, że prosty rysunek czyni zadość wszystkim warunkom wymaganym zdaniem dziecka od obrazu" (Arnheim, 2019, s. 182). I kolejne ważne podkreślenie, że częste powracanie dziecka do już przyswojonej i opanowanej formy plastycznej jest prawidłowością rozwojową, zgodnie z "gestaltyczną" zasadą prostoty (Arnheim, 2019). Proces strukturalizacji formy plastycznej obrazowania łatwo uchwycić, np. między bezcelowym zawijasem, będącym efektem ruchu ekspresyjnego w fazie bazgrot (kinestetycznej), a kształtem celowym, kontrolowanym wzrokiem, będącym wynikiem ruchu opisowego $\mathrm{w}$ fazie kodyfikacji (symbolizacji). W doznaniu intencjonalnym dziecka linearna krzywa bardzo szybko przemienia się w dwuwymiarowy przedmiot obrazowy (Arnheim, 2019). Prawdopodobnie ta postrzeżeniowa transformacja, w opinii Arnheima, leży również u podstaw - „uświadomienia sobie, że kształty narysowane [...] mogą zastępować wszelkie przedmioty, do których pozostają w stosunku znaczący-znaczony" (Arnheim, 2019, s. 190). Ma rację badacz, że w praktyce trudno w sposób jednoznaczny określić, w którym momencie rozwoju formy obrazowania dziecko po raz pierwszy wyznacza sformułowanemu przez siebie pojęciu funkcję przedstawienia. Podpisuję się pod myślą Arnheima, że każdy nauczyciel powinien być wyposażony w wiedzę umożliwiającą „uchwycenie związków między formą zauważoną i wynalezioną, postrzegania przestrzeni zależnie od tworzywa dwu- lub trójwymiarowego, współzależności między typowym zachowaniem motorycznym a kontrolą wzrokową, a także ścisłych powiązań między percepcją a wiedzą" (Arnheim, 2019, s. 176).

W modelu obrazowania kluczowym sformułowaniem jest pojęcie schematu (Lowenfeld, Brittain, 1977; Szuman, 1990b; Arnheim, 2019). Bezkompromisowym przeciw- 
nikiem samego określenia jest Arnheim, choć pojęcie to stanowi konstatację jego idei. Badacz uważa, że termin „schemat” jest nieadekwatny i niewłaściwy do opisu zjawisk sztuki dziecka i sztuki w ogóle. I w zasadzie można by mu przyznać rację, ale pojęcie to jest głęboko zakorzenione w tradycji psychologii i pedagogiki, szczególnie sztuki dziecka, i nie zawsze w ujęciu negatywnym. W swoim myśleniu o twórczości plastycznej dziecka Arnheim rezygnuje więc z terminu „schemat”, wprowadzając w zamian określenie „pojęcia przedstawieniowe”. Wiele uwagi poświęca naturalnym powiązaniom i zależnościom rozwojowym wynikającym $\mathrm{z}$ aktywności poznawczej i aktywności plastycznej dziecka. Twórczość plastyczną dziecka traktuje jako narzędzie, które „służy identyfikowaniu, rozumieniu i określaniu rzeczy, które pomaga badać wzajemne związki i tworzyć porządek coraz wyższego rzędu" (Arnheim, 2019). Pojawia się uwaga Arnheima, ważna dla praktyki pedagogicznej, że w przebiegu rozwoju formy plastycznej ,idealne następstwo z grubsza tylko odpowiada temu, co obserwujemy w każdym pojedynczym przypadku" oraz że różne dzieci, przechodzą przez różne fazy rozwoju formy plastycznej, w innym czasie, zależnie od indywidualności (Arnheim, 2019, s. 197).

Wymiernym kluczem poznania i oceny twórczości plastycznej dziecka może być przedstawiony tutaj w pewnym skrócie myślowym opis stadiów rozwoju formy plastycznej obrazowania zgodnie z wyznaczoną typizacją.

\section{Stadium prefiguratywne.}

W obrazowaniu dziecka zaczyna się od pierwszej uchwyconej bazgroty (Parnowska-Kwiatkowska, 1960; Kellogg, 1967; Szuścik, 2019). Bazgrotę uważa się za najbardziej szczery i autentyczny wyraz dziecięcego stosunku do świata, podkreśla się też jej ogólnorozwojową wartość (Lowenfeld, Brittain, 1977; Arnheim, 2019; Szuścik, 2019). Pierwsze bazgroty nie są reprezentacją, nie mają celu przedstawienia, są wynikiem aktywności motorycznej i ekspresją ruchu. Dziecko bazgrać zaczyna od „skakania” narzędziem rysunkowym po papierze. Posługuje się linią, a jej kształt, długość, kierunek zależy od budowy ramienia i dłoni, temperamentu, nastroju i osobowości dziecka (Lowenfeld, Brittain, 1977; Trojanowska, 1983; Popek, 1985; Arnheim, 2019).

W fazie pierwszej stadium - bazgrot (kinestetycznej) - „gryzmołki bazgrotalne" są chaotyczne i przypadkowe. Dziecko nie panuje nad rozmachem ramienia i zaciśniętej dłoni, nie kontroluje ruchu. Sytuacja zmienia się w niedługim czasie. Stopniowo zaczyna ono kontrolować swoje ruchy. Ukazują się różne elementy formy, najpierw punkty, linie proste rozmachowe, oderwane i ciągłe, naturalnie skupione, nakładające się na siebie, następnie ujawnia się zygzak wahadłowy, wahadłowo-eliptyczny i zmienno-kierunkowy. Treścią jest ruch z całą jego emocjonalną zawartością. Dziecko swoją uwagę skupia na uzyskaniu kontroli nad kształtem linii. Pojawia się akcent dla praktyki - dziecko w tej fazie rozwoju formy, z powodu braku koordynacji wzrokowo-ruchowej nie jest gotowe do podejmowania 
zadań, które wymagają precyzji, je wolno i niezgrabnie, ma problemy z zapinaniem i rozpinaniem guzików, z czynnościami samoobsługowymi i innymi (Lowenfeld, Brittain, 1977; Uberman, 2015).

W drugiej fazie tego stadium - synergii (koordynacji) (u Lowenfelda i Brittaina - stadium bazgrot kontrolowanych, u Arnheima - stadium bazgrot ekspresyjno-opisowych) dziecko odkrywa związek pomiędzy ruchem ręki a pojawiającym się na kartce papieru znakiem. Ruch ekspresyjny przeradza się w ruch ekspresyjno-opisowy. W bazgrotach pojawia się nowa forma obrazowania, określana jako przełomowa, ważna dla rozwoju dziecka - kształt spiralny. Pojawienie się spirali Arnheim odczytuje jako jeden $\mathrm{z}$ cudów natury. $\mathrm{Z}$ pedagogicznego punktu widzenia jest to ważny komponent $\mathrm{w}$ rozwoju formy plastycznej, ponieważ sygnalizuje początek koordynacji zachowań motorycznych dziecka. Podobnie sądzą Lowenfeld i Brittain, Trojanowska, Szuścik, Kellogg. W tym miejscu pojawia się podkreślenie dla praktyki, że jest to czas, w którym dziecko chętnie podejmuje różne czynności manipulacyjne i samoobsługowe. Jest to moment ważny dla rozwoju twórczości plastycznej, ponieważ od teraz zaczyna się świadome obrazowanie, które w ocenie Arnheima ma swoje źródło w ruchu opisowym ręki (ruch spiralny jest równoznaczny $z$ ruchem obrotowym ręki).

Elementami formy plastycznej są: kształty spiralne, linie proste układające się w różnym kierunku, linie faliste, łamane, krzywe (pętelki), linie zygzakowate, krzyżujące się. Obserwuje się rozwojowe dążenie do różnorodności kształtów, ich wzbogacania, komplikowania (kontrasty i podobieństwa formy). Zamknięcie obrazowania na płaszczyźnie kartki oznacza, że bazgrota traci swoją ekspresyjną przypadkowość. Zmienia się również widocznie dynamika ruchu z dotychczasowego niekontrolowanego i ekspresyjnego w ruch kontrolowany i ekspresyjno-opisowy. Kolor pojawia się zupełnie przypadkowo, przestrzeń dziecko pojmuje cieleśnie i jest ona równoznaczna z ruchem rysowania. Treścią obrazowania w tej fazie jest nadal ruch. Dziecko nabywa umiejetności posługiwania się linią i kształtem, jego rysunkowe „zakrętasy wyraźnie łagodnieją i ulegają strukturalnemu uproszczeniu, rozwojowo podąża ono ku zamknięciu kształtu koła. Obserwowalne jest zainteresowanie materią, fakturą, lepieniem, konstruowaniem, a także zamiłowanie do łączenia różnych elementów w jedną całość. Obszerną morfologię bazgrot dziecięcych opracowały i prace swoje poświęciły Maria Parnowska-Kwiatkowska (1960), Rhoda Kellogg (1967), Urszula Szuścik (2019).

II. Stadium motywów figuratywnych (tematycznych).

Kolejnym stadium rozwoju formy plastycznej w obrazowaniu dziecka jest stadium motywów figuratywnych (tematycznych). W stadium tym wyróżnia się dwie fazy: kodyfikacji (symbolizacji) i reifikacji (uprzedmiotowienia). 
Faza kodyfikacji (symbolizacji) rozpoczyna się wraz z pojawieniem się kształtu koła - to moment przełomowy nie tylko dla rozwoju formy obrazowania, ale rozwoju w ogóle, znaczący dla praktyki pedagogicznej i edukacji dziecka (Uberman, 2019). Pojawienie się kształtu koła w rysunkach dziecka jest różnie rozumiane i interpretowane. W rozwoju psychicznym pojawienie się symbolu pełni jest równoznaczne $\mathrm{z}$ etapem separacji ego od Jaźni, czyli zaczątkiem indywidualnej świadomości (Dudek, 2006; Uberman, 2019). Carl G. Jung pojawienie się kształtu koła w rysunkach dziecka postrzega jako względną wartość i całość pojedynczych psyche (Jung, 1952; Jacobi, 1968), totalność psychiczną (Jacobi, 1968).Kształt koła jest symbolem świadomości siebie, odrębności, poczucia bezpieczeństwa, „magicznym kołem", psychiczną mandalą, symbolem budowanej osobowości (Jung, 1995). Uosabia „odłączenie od matki”, zaczątek własnego „Ja” (ego) (Jung, 1981) oraz „początek dochodzenia do nadświadomości (Jacobi, 1968), czyli „budowania świata przez wyodrębnienie i rozróżnienie” (Jacobi, 1968). Oznacza całość i jedność, pełnię psychiczną. W obrazowaniu dziecka pojawia się samorzutnie i jest „wyrazem faktycznych narodzin Jaźni” (Jung, 1981). Kształt koła w rozwoju obrazowania jest punktem wyjścia, prawzorem dla tworzonych najpierw wzorów słonecznikowych, promienistych, w przyszłości motywów tematycznych (dom, drzewo, pojazd, człowiek), procesem ważnym dla rozwoju psychicznego ze względu na formowanie się indywidualnej i integralnej struktury psychicznej, której początkiem jest pierwotna Jaźń, owa „transcendująca świadomość, centralna instancja psychiczna, która zarazem zdaje się zawierać w sobie aprioryczny cel rozwoju osobowości: jej jedność i całość" (Jung, 1981). Sądzę, podobnie jak Arnheim, że kształt koła w rysunku dziecka jest wzorem formalnym, i zgadzam się z tezą Junga, że jest symbolem kultury, który, podkreślam, dziecko powinno odkryć samodzielnie. Poznać i doświadczyć jego pełni, a dlaczego wyjaśnia obrazowo Jung, za pomocą pewnej baśni (Jung, 1981, s. 145-146).

Zamknięty kształt koła jest niewątpliwie zalążkiem rysunku tematycznego, w którym dziecko próbuje nadać określoną formę światu spostrzeganemu. Jego uczucia i wyobrażenia aktywizują się, bazując na zależności: ekspresja - spostrzeganie (Trojanowska, 1983). Faza kodyfikacji wiąże się z nazywaniem bazgrot. Nazywanie bazgrot pojawia się wraz z kształtem koła. W rozwoju formy plastycznej i rozwoju w ogóle jest to wyjątkowo ważny moment, dowodzi bowiem, że zmienił się sposób myślenia dziecka, że przeszło ono od myślenia kinestetycznego do myślenia wyobrażeniowego. Nazywanie bazgrot sygnalizuje też początek kształtowania się podłoża pamięci wzrokowej (Lowenfeld, Brittain, 1977). Dziecko interesuje się czynnością rwania, cięcia i naklejania papieru. Treść wzbogaca się o temat, choć ma on jeszcze charakter zmienny, nierówny (Trojanowska, 1983; Arnheim, 2019). Kształt koła w myśli Arnheima to kształt rozmyślnie zaokrąglony i zamknięty, określony linią konturową. Jest najprostszym kształtem, jaki można 
uzyskać w medium obrazowym i daje początek nie tylko wzorom słonecznikowym, promienistym, ale też pierwszemu wizerunkowi człowieka.

Elementy formy wizualnej tej fazy to: kształt koła, wzory słonecznikowe, promieniste, „głowonogi”, ujawnia się eksploracyjne zainteresowanie kolorem, przestrzeń jest pojmowana nadal cieleśnie; najważniejszym rozwojowo komponentem formy jest kształt - kształt koła - dziecko świadomie zamyka przestrzeń i poszukuje formy obrazowej; podstawowym narzędziem aktywności plastycznej są nożyczki, techniką wycinanie, ponieważ dzięki niemu daje się określić kształt bardziej konkretnie. Ważna uwaga - czynność wycinania sprzyja formułowaniu schematu, do którego rozwojowo dąży dziecko. Należy również dodać, że faza kodyfikacji to przede wszystkim faza kształtu i linii konturowej w rozwoju formy, w rozwoju osobowości - manifestującej świadomości siebie.

Faza reifikacji (uprzedmiotowienia) u Lowenfelda i Brittaina to stadium przedschematyczne, u Arnheima pierwszych form przedstawieniowych. Jest to czas, w którym w twórczości plastycznej dziecko jest emocjonalnie zaangażowane we wszystko, co dzieje się wokół niego. Aktywność plastyczna jest „ucieleśnieniem jego samego”. Zdaniem Lowenfelda i Brittaina jest to czas, w którym „kształtują się wzorce zachowania, za sprawą których dziecko może wyrosnąć na osobę twórczą lub przeciwnie osobę niepotrafiącą myśleć samodzielnie" (1977, s. 80). Suponują też, że jest to okres w rozwoju formy plastycznej, w którym szczególnie powinno się stymulować i motywować dziecko do podejmowania aktywności plastycznej, a jednocześnie przestrzegają, że nie można „pozytywnie oddziaływać na zachowanie dziecka, dostarczając mu wzorów czy metod naśladowania, które pozwoliłyby mu uzyskać lepiej wyglądający wytwór. Zmiana w wytworze powinna być wynikiem zmian w myśleniu, odczuwaniu i spostrzeganiu dziecka. Dzięki temu procesowi zachodzą zmiany w zachowaniu i wzorcach rozwojowych" (Lowenfeld, Brittain, 1977, s. 86). Arnheim natomiast wskazuje na rozwojowe przyswajanie najprostszej zależność między kierunkami pion - poziom. Kąt prosty jest asumptem pionowo-poziomego układu odniesienia, wzorem symetrycznym porządkującym przestrzeń na płaszczyźnie, fundamentem dla całej koncepcji przestrzeni. O przestrzennym zintegrowaniu układu pionowo-poziomego można mówić w ocenie Arnheima w chwili pojawienia się linii podstawy (Arnheim, 2019).

Elementy formy plastycznej tej fazy są: kształty organiczne (koło, prostokąt, kwadrat, trójkąt), kształt budowany linią konturową, wypełniany plamą barwną, przestrzeń subiektywna (obrazki rentgenowskie i zaginanie), upodobania kolorystyczne, kontrastowe układy barwne, doznania intencjonalne (wyolbrzymienia), kinestetyczne, emocjonalne (kolorystyka) są prawidłowością w tej fazie rozwoju, znikają wraz z pojawieniem się obiektywizacji myślenia, motywy tematyczne (człowiek, dom, pojazd, drzewo, inne). 
III. Stadium utworów figuratywnych.

Ostatnim stadium w rozwoju obrazowania figuratywnego dziecka jest stadium utworów figuratywnych. Faza symplifikacji (schematu) przypada na okres geometryzacji u Lowenfelda i Brittaina, to stadium schematu, u Arnheima, pojęć przedstawieniowych. W opinii Stefana Szumana schemat rysunkowy jest fundamentem rozwoju dziecka w ogóle (1990b). Podkreśla on wielokrotnie, że dziecko stwarzając uproszczony schemat przedmiotu, konstruuje go, a nie naśladuje, że schemat rysunkowy daje pogląd na daną rzecz, ale nie daje jej obrazu (oglądu). Na ogół badacze twórczości plastycznej dziecka są zgodni w ocenie wartości rozwojowej schematu rysunkowego, szczególnie jeżeli chodzi o odkrycie linii podstawy, podobnie jak wcześniej kształtu koła i kształtu spirali. Różnią się nieco w jego opisie. Schemat rysunkowy formuje się w twórczości plastycznej dziecka dość wcześnie, formą zalążkową jest kształt koła. Uformowanie się schematu rysunkowego (u Arnheima pojęcia przedstawieniowego) ujawnia obiektywizację myślenia. Pojęciowo schemat obejmuje nie tylko kształty, lecz także barwy (kolor lokalny), pojęcie przestrzeni (linia podstawy i linia nieba), układ kompozycyjny (uporządkowanie i harmonia), faktury, zapachy, dźwięki, smaki. Plastyczne określenie świata rzeczywistego jest równoznaczne z jego nazywaniem, oswajaniem, zdobywaniem. W ocenie Lowenfelda i Brittaina takie określenie schematyczne świata, które reprezentuje trwale dane przedmioty oraz ich powiązanie na linii podstawy, świadczy o przejściu na wyższy poziom rozwoju umysłowego. Znaczącym sądem dla praktyki pedagogicznej jest myśl badaczy dotycząca nauki czytania i pisania. Twierdzą oni, że „jeżeli dziecko potrafi dostrzec logiczne związki między przedmiotami w swym otoczeniu, można więc myśleć o sensownym programie nauki czytania. W czytaniu bowiem to samo dostrzeganie związków jest niezbędne po to, aby dziecko umiało łączyć poszczególne litery w celu utworzenia symbolu słowa [...]. Zmuszanie dziecka do nauki czytania zanim osiągnie odpowiedni poziom gotowości może spowodować powstanie negatywnych postaw wobec czytania; postawy te są trudne do zniwelowania i nie zrównoważy ich żadna korzyść, wynikająca z organizacji nauki dziecka w ramach jakiegoś dowolnie przyjętego programu" (Lowenfeld, Brittain, 1977, s. 104). Pojawienie się w rysunkach dziecka linii podstawy Edyta Gruszczyk-Kolczyńska (1992) łączy z rozwojem pojęć matematycznych i gotowością dziecka do podjęcia nauki matematyki. Podobnie jak schemat kształtu dziecko odkrywa schemat barwy. Rozwojowo jest to ważny moment, ponieważ ustalenie określonej barwy dla danego przedmiotu i trwałe jej powtarzanie jest bezpośrednim odbiciem dalszego rozwoju procesów myślowych. I, co znaczące, jest to moment, w którym zaczyna się rozwijać zdolność klasyfikowania przedmiotów oraz umiejętność dokony wania generalizacji. Samo uświadomienie sobie, że kolor przedmiotu na obrazku odpowiada kolorowi przedmiotu, w rzeczywistości jest 
ważnym odkryciem, dającym zadowolenie i satysfakcję dziecku, a z pedagogicznego punktu widzenia może oznaczać, że zaczyna ono wykrywać pewien logiczny porząadek w świecie przedmiotowym i ustanawiać konkretne relacje z nim. Schemat barw jest więc przejawem rozwijającej się zdolności myślenia abstrakcyjnego, a także sygnalizuje, że dziecko jest zdolne do przenoszenia swoich doświadczeń na inne sytuacje. Należy podkreślić, że pod żadnym pozorem w tej fazie rozwoju nie powinno się nakłaniać dziecka do obrazowania przedmiotów „właściwymi” według dorosłych barwami i uczyć zasad perspektywy. Schemat barw powinno odkryć samodzielnie, tak jak schemat linii podstawy, kształt koła i spirali.

Elementy formy plastycznej: obiektywne pojęcie przestrzeni - linia podstawy, linia nieba, schemat barw, uporządkowany układ kompozycyjny, trwała stabilizacja kształtu i barwy. Treść jest związana z rzeczywistością codzienną, zanikają wyolbrzymienia intencjonalne.

Faza egzemplifikacji (ilustracji) jest ostatnią fazą wyodrębnioną w rozwoju formy plastycznej obrazowania, ujawnia się na ogół ok. 8.-9. roku życia. Jest to już początek ilustracji o cechach realizmu wizualnego. Dziecko porzuca geometryzacyjny schemat rysunkowy przedmiotów na rzecz miękkiego konturu. Konturem płynnie opisuje przedmiot, włączając pomijane przedtem drobne szczegóły. Zmienia się także stosunek do barwy, która traci swoją umowną trwałość związku z przedmiotem na rzecz dekoracyjności i subiektywizacji. Zmienia się pojęcie przestrzeni, pojawia się perspektywa kulisowa, a także podniesiona linia horyzontu. Znika infantylna perspektywa intencjonalna, obiektywizują się rozmiary przedmiotów i postaci. Na miejsce dotychczasowych schematycznych form geometrycznych pojawią się kształty organiczne. Jest to czas, w którym dziecko uświadamia sobie przynależność do określonej społeczności rówieśniczej. Staje się coraz bardziej świadome własnego świata, pełnego różnych emocji, często ukrywanych przed dorosłymi. Jest też bardziej krytyczne w stosunku do siebie i innych. Niechętnie pokazuje swoje wytwory, często też samo odnosi się do nich z pewnym poczuciem bezsensowności, beznadziejności, ze stwierdzeniem braku talentu itd. Zanika charakterystyczna dla wcześniejszych stadiów spontaniczność, żywość i naturalność.

\section{PODSUMOWANIE}

Nauczyciel ma przed sobą ważne zadanie - poznanie i ocenę wytworu plastycznego dziecka zgodnie z jego możliwościami poznawczymi i percepcyjno-motorycznymi. Aby oceniać, najpierw należy poznać. Dziecko pragnie, by „nauczyciel był kimś, kto pozwala mu nawet czegoś nie wiedzieć, lecz kto poważnie traktuje to, co myśli, 
kto sam cieszy się życiem i pozwala mu uczynić to na swój własny sposób, kto uznaje ważne dla dziecka wartości” (Lowenfeld, Britain, 1977, s. 107).

Reasumując, w poznaniu i ocenie twórczości dziecka ważna jest osoba nauczyciela. Brak elementarnej wiedzy, znajomości dziecka i jego potrzeb przekłada się na wygórowane, nieadekwatne do rozwoju i możliwości kryteria oceny. Rysunki dziecka należy traktować jako dokument jego rozwoju, a nie jak coś, co należy korygować i poprawiać. W praktyce należy zapomnieć o tezie Luqueta, że „dziecko rysuje to, co wie o przedmiocie, a nie to, co widzi”. Rysunek dziecka jest jak mapa: „Trzeba znaleźć rzeki, góry, drogi, dróżki, dostrzec doliny, lasy, prowadzić wzrok, tak, by móc za pomocą symbolicznych oznaczeń zbudować wyobrażenie nastroju, kolorytu, idei" (Michejda-Kowalska, 1987, s. 31). Poznanie i ocena powinny być merytoryczne i polegać na wspólnym oglądaniu wytworu z dzieckiem, grupą przedszkolną, zespołem klasowym, jego omówieniem formalnym i treściowym (tematycznym). Swoje rozważania zakończę myślą Władysława Lama, która moim zdaniem oddaje w pełni ideę pedagogicznego poznania i oceny twórczości plastycznej dziecka: „Nauczyciel nie powinien w omawianiu prac i w osądzaniu ich dopuścić do ustalenia się poglądu, że jakieś dziecko lub jakaś forma obrazu jest ideałem godnym naśladowania. Przeciwnie, jest bardzo wskazane, aby nauczyciel umiał wykazać, że w rozwiązywaniu każdego zagadnienia istnieje szereg różnych możliwości. Jeśli potrafi udowodnić, że najbardziej onieśmielone dziecko [...] godne jest pochwały, gdyż wykazało pewną możliwość samodzielnego stwarzania obrazu, spełni bardzo słuszny i ważny moment (stymulowania, motywowania MU). Trzeba jednak umieć dostrzec tego rodzaju momenty i nie dopuścić do ich zagubienia i zaniku w pracy dziecka. Twierdzenie, że są dzieci niezdolne, dyskwalifikuje nauczyciela" (1960, s. 62-63).

\section{WNIOSKI}

1. Pedagogiczne poznanie i ocena twórczości plastycznej dziecka wymaga wymiernych kryteriów analizy formy plastycznej wytworu (jakości wizualne, jedność ideowa formy i treści, odniesienie do autentycznych możliwości dziecka).

2. W poznaniu i ocenie twórczości plastycznej dziecka należy kierować się myślą Celestyna Freineta, że dziecięcy „rysunek nie może być na miarę wychowawcy, lecz na miarę psychiki dziecka” (1976, s. 8). 


\section{LITERATURA}

Arnheim, R. (2019). Sztuka i percepcja wzrokowa. Psychologia twórczego oka. Łódź: Officyna.

Bruner, J.S. (1982). Poza dostarczone informacje. Studia z psychologii poznawania. Warszawa: PWN.

Cannoni, E. (2003). Il disengo dei bambini. Rzym: Carocci editore.

Dudek, Z.W. (2006). Psychologia integralna Junga. Warszawa: Eneteia.

Freinet, C. (1976). O szkołę ludową. Pisma wybrane. Wrocław: Ossolineum.

Golomb, C. (2011). The Creation of Imaginary Worlds: The role of art., magic and dreams in child development. London: Jessica Kingsley Publishers.

Gombrich, E. (1981). Sztuka i złudzenie. O psychologii przedstawienia obrazowego. Warszawa: PIW.

Gruszczyk-Kolczyńska, E. (1992). Dzieci ze specyficznymi trudnościami w uczeniu się matematyki. Warszawa: WSiP.

Jacobi, J. (1968). Psychologia C.G. Junga. Warszawa: PAX.

Jung, C.G. (1952). Psychologie und Alchemie. Rascher-Verlag, Stuttgart-Zurich, 1944, wyd. II 1952.

Jung, C.G. (1981). Archetypy i symbole. Pisma wybrane. Warszawa: Czytelnik.

Jung, C.G. (1995). Podstawy psychologii analitycznej. Wykłady tavistockie. Warszawa: Wrota.

Kellogg, R. (1967). Rhoda Kellogg Child Art. Collection. Washington 1967.

Kindler, A. Darras, B. (1997). Map of artistic development. Child development in art. Reston: National Art Education.

Kościelecki, S. (1976). Współczesna koncepcja wychowania plastycznego. Warszawa: PWN.

Kujawiński, J. (1990). Rozwijanie aktywności twórczej uczniów klas początkowych. Warszawa: WSiP.

Lam, W. (1960). Sztuka dziecka. Warszawa: Nasza Księgarnia.

Longobardi, C., Pasta, T., Quaglia, R. (2012). Manuale del disengo infantile. Seconda edizione. UTET University.

Lowenfeld, V., Brittain, W.L. (1977). Twórczość a rozwój umysłowy dziecka. Warszawa: PWN.

Luquet, G.H. (1927). Le dessin enfantin. Paris: Alcan.

Marciniak, T. (1976). Problemy wychowania plastycznego. Warszawa: Nasza Księgarnia. Michejda-Kowalska, K. (1987). Czy kolor różowy może być smutny. Warszawa: WSiP. Parnowska-Kwiatkowska, M. (1960). Bazgrota i rysunek dziecka. Warszawa: Nasza Księgarnia.

Piaget, J. (1966). Studia z psychologii dziecka. Warszawa: PWN. 
Piaget, J. (1981). Równoważenie struktur poznawczych: centralny problem rozwoju. Warszawa: PWN.

Popek, S. (1985). Analiza psychologiczna twórczości plastycznej dzieci i młodzieży. Warszawa: WSiP.

Stern, A. (2016). Odkrywanie śladu. Gliwice: Element.

Szuman, S. (1990a). O sztuce i wychowaniu estetycznym. Warszawa: WSiP.

Szuman, S. (1990b). Sztuka dziecka. Psychologia twórczości rysunkowej dziecka. Warszawa: WSiP.

Szuścik, U. (2018). Twórczość rysunkowa dziecka w kontekście tworzenia przez nie znaku plastycznego i odkrywania znaczenia. Forum Pedagogiczne, 2, 33-46.

Szuścik, U. (2019). Bazgrota w twórczości plastycznej dziecka. Katowice: Wyd. UŚ.

Trojanowska, A. (1983). Dziecko i plastyka. Warszawa: WSiP.

Uberman, M. (2015). Vyvoj figurativneho motivu v detskom vytvarnom prejave.

Prešov: Wyd. Pavol Šidelský, Akcent Print.

Uberman, M. (2019). Od kształtu koła do wizerunku człowieka - obrazowania figuratywne dziecka w perspektywie poszukiwań archetypowo-mitycznych symboli kultury. W: J. Bonar. M. Wiśniewska-Kin. A. Buła (red.). Horyzonty dziecięcych znaczeń. Kreowanie środowiska uczenia się (s. 83-96). Łódź: Wyd. UŁ.

Wygotski, L.S. (1971). Wybrane prace psychologiczne. Warszawa: PWN.

\title{
PEDAGOGICAL CRITERIA OF COGNITION AND EVALUATION OF CHILDREN'S DRAWINGS IN THE PERSPECTIVE OF THE MODEL OF FIGURATIVE IMAGING
}

\begin{abstract}
Introduction: Groping in the dark, over-theorising, subjectivity of recognition and evaluation of children's artistic creativity are responsible for lowering children's self-esteem and making them dependent on adults instead of stimulating, motivating and bosting children's self-esteem. The lack of criteria of recognition results in superficial analyses, hasty diagnoses and assessments that are inadequate for children's development and abilities. Purpose: The article analyses the literature on the subject of children's artistic creativity within the figurative imaging period, focusing on showing visual values of plastic form that can be treated as a clear-cut criterion for pedagogical recognition and objective evaluation of children's drawings. It shows which visual elements of the plastic form of children's drawings should be considered; how developmentally different are the notions of line, shape, colour, space and compositional structure; which new formal features can be ascribed to children's drawings in the period of figurative imaging. State of knowledge: The notion of recognition and evaluation of children's drawings was undertaken by Stefan Szuman in the 60s of XX century. Some references to those issues can be found in the research by, among others, Victor Lowenfeld and William L. Brittain, Rudolf Arnheim, as well as Stanisław Popek. Pedagogical recognition and evaluation of children's drawings is represented in the description of the development of plastic form in
\end{abstract}


the model of figurative imaging by Marta Uberman. Summary: Pedagogical recognition and evaluation of children's artistic creativity should be objective and based on measurable key of qualitative-quantitative analysis of the plastic form of the given work.

Keywords: children's drawings, figurative imaging, pedagogical recognition and evaluation, visual values of plastic form 